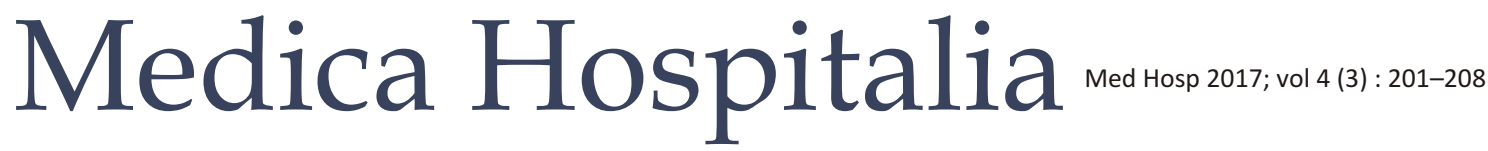

Original Article

\section{Faktor Risiko yang Berpengaruh terhadap Kejadian Preeklampsia pada Kehamilan di RSUP Dr. Kariadi Semarang Tahun 2015}

\author{
Yahya Renaningrum ${ }^{1}$, Elisa Ulfiana ${ }^{2}$, Ida Ariyanti ${ }^{2}$ \\ ${ }^{1}$ Bidan RSUP Dr. Kariadi Semarang \\ ${ }^{2}$ Dosen Poltekkes Kemenkes Semarang
}

\begin{abstract}
Abstrak
Latar belakang : Preeklamsia adalah penyakit dalam kehamilan yang menyebabkan morbiditas dan mortalitas yang tinggi bagi ibu dan bayi yang dikandungnya. Sampai saat ini penyebab pasti Preeklamsia belum diketahui. Perlu dilakukan penelitian untuk mengidentifikasi faktor risiko kejadian Preeklamsia dan mengontrolnya sehingga memudahkan untuk dilakukan pencegahan primer. Penelitian ini bertujuan untuk mengetahui faktor risiko yang berpengaruh terhadap kejadian Preeklamsia pada ibu hamil di RSUP Dr. Kariadi Semarang.

Metode : Penelitian ini menggunakan desain penelitian case control dengan pendekatan retrospektif menggunakan data rekam medis dan menggunakan Odds Ratio sebagai uji statistik untuk melihat seberapa besar pengaruh faktor risiko terhadap kejadian Preeklamsia. Sampel yang digunakan sebesar 106, 53 sampel kasus dan 53 sampel kontrol. Teknik sampling menggunakan simple random sampling.

Hasil : Dari hasil penelitian ini dapat disimpulkan bahwa dari 11 variabel yang diteliti 7 variabel adalah faktor risiko Preeklamsia. Faktor risiko tersebut adalah: riwayat Preeklamsia (OR 3,88), penyakit DM (OR 2,039), penyakit ginjal (OR 2,038), Hipertensi kronis (OR 12), IMT (OR 4,397), usia (OR 1,461), dan jarak kehamilan (OR 2,233). Faktor risiko yang paling berpengaruh adalah Hipertensi kronis. Paritas $(O R 0,796)$ dan riwayat menikah $(O R \quad 0,185)$ adalah 2 variabel yang merupakan faktor protektif Preeklampsia. Kehamilan multipel dan penyakit APS dalam penelitian ini bukanlah faktor risiko kejadian Preeklamsia.

Simpulan : Hasil penelitian ini diharapkan dapat digunakan untuk deteksi dini kejadian Preeklampsia pada ibu hamil. Kepada masyarakat agar menghindari faktor risiko tersebut dan rutin memeriksakan kehamilan pada tenaga kesehatan.
\end{abstract}

Kata kunci : faktor risiko, kehamilan, preeklampsia

\author{
Risk factor of preeclampsia in \\ pregnancy in RSUP Dr. Kariadi Hospital \\ Semarang in Year 2015
}

\begin{abstract}
Background : Preeclampsia is a disease in pregnancy that cause high morbidity and mortality for both mother and baby. Until now, the exact cause of Preeclampsia is unknown. Need further research to identify risk factors of Preeclampsia and control, making it easier to do primary prevention.This study aim to identify risk factors that influence the incidence of Preeclampsia in pregnant women at the Hospital Dr. Kariadi Semarang.

Methods : The design of this study was a case control with retrospective study of medical records and viewed using Odds Ratio as statistical tests to see how big the effect of risk factors on the incidence of Preeclampsia. This study use 106 samples, 53 samples for case and 53 samples for control. Sampling technique use simple random sampling.

Results : From this result it can be concluded that of the 11 variables studied 7 variables are risk factors, 2 variables are protectif factors, and 2 variables are not risk factors for Preeclampsia. The risk factors are : a history of Preeclampsia (OR 3.88), DM (OR 2.039), kidney disease (OR 2.038), chronic hypertension (OR 12), IMT (OR 4.397), age (OR 1.461), and interval of pregnancies (OR 2.233). Chronic hypertension is the most influence risk factor. Parity (OR 0.796), and history married (OR 0.185) were protective variables factors of Preeclampsia. APS disease and multiple pregnancy in this study are not a risk factor for the incidence of Preeclampsia.

Conclusion : The results of this research can be used for early detection of Preeclampsia in pregnant women. The public should avoid the risk factors and have routine antenatal at health care provider.
\end{abstract}

Keywords : risk factor, pregnancy, Preeclampsia 


\section{PENDAHULUAN}

Preeklampsia adalah penyakit dalam kehamilan yang mengakibatkan mortalitas dan morbiditas yang tinggi, tidak hanya untuk ibu tapi juga bagi bayi yang dikandungnya. Data menunjukkan bahwa tiga penyebab kematian ibu tertinggi di dunia yaitu perdarahan, infeksi, dan preeklamsia. Prevalensi preeklamsia di negara maju adalah 1,3-6\% dan di negara berkembang adalah $1,8-18 \%{ }^{1}$

Angka Kematian Ibu (AKI) di Provinsi Jawa Tengah pada tahun 2014 sebesar 126,65 / 100.000 KH (711 kasus), meningkat dibanding periode tahun 2012-2013 yaitu sebesar 116,34 / 100.000 KH (675 kasus) pada tahun 2012 dan 118,62 / 100.000 KH (668 kasus) pada tahun 2013. Di kota Semarang jumlah kematian ibu juga meningkat yaitu sebanyak 29 kasus pada tahun 2013, 33 kasus pada tahun 2014, dan 35 kasus pada tahun 2015. Pada tahun 2014 kematian ibu tertinggi adalah karena Preeklampsia $(48,48 \%)$. Penyebab AKI lainnya adalah karena perdarahan $(24,24 \%)$, disebabkan karena penyakit $(18,18 \%)$, infeksi $(3,03 \%)$ dan lain-lain $(6,06 \%)$. Hal ini membuat Preeklampsia masih menjadi masalah dalam pelayanan obstetri di Indonesia khususnya di kota Semarang. ${ }^{2}$

RSUP Dr. Kariadi Semarang sebagai salah satu rumah sakit PONEK (Pelayanan Obstetri Neonatal Emergensi Komprehensif), dan rumah sakit tersier di kota Semarang di provinsi Jawa Tengah, merupakan tempat rujukan pasien dengan diagnosa Preeklampsia / eklampsia. Perawatan pasien merujuk pada Pedoman Nasional Pelayanan Kedokteran (PNPK) Preeklampsia yang dituangkan dalam Petunjuk Praktik Klinik (PPK) RSUP Dr. Kariadi. Dalam PPK telah tertulis dengan jelas langkah langkah pengkajian data, penegakan diagnosa sampai dengan penatalaksanaan.

Preeklampsia adalah 10 besar diagnosa yang ada di ruang Obstetri RSUP Dr. Kariadi Semarang. Pada tahun 2015 dari 1585 ibu hamil yang dirawat sebanyak 327 pasien $(20,63 \%)$ dirawat dengan diagnosa Preeklampsia. 19 pasien (5,8\%) dari 327 ibu dengan diagnosa Preeklampsia berlanjut menjadi eklampsia dan jumlah pasien meninggal sebanyak 8 pasien $(2,47 \%)$, sisanya $(91,72 \%)$ pulang dalam keadaan sehat.

Perjalanan penyakit Preeklampsia pada awalnya tidak memberi gejala dan tanda, namun pada suatu ketika dapat memburuk dengan cepat. Hingga saat ini penyebab pasti terjadinya Preeklampsia masih belum diketahui. Praktisi kesehatan diharapkan dapat mengidentifikasi faktor risiko Preeklampsia dan mengkontrolnya, sehingga memudahkan dilakukannya pencegahan primer. ${ }^{1}$

Faktor risiko Preeklampsia dapat dideteksi sejak awal sehingga dapat dilakukan langkah-langkah pencegahan agar tidak terjadi komplikasi yang lebih buruk lagi. Faktor risiko Preeklampsia adalah usia $>40$ tahun, IMT >35, nulipara, multipara dengan riwayat preeklamsia sebelumnya, multipara dengan kehamilan oleh pasangan baru, multipara dengan jarak kehamilan sebelumnya 10 tahun atau lebih, riwayat Preeklampsia pada ibu atau saudara perempuan, kehamilan multipel, IDDM (Insulin Dependent Diabetes Mellitus), hipertensi kronik, penyakit ginjal, dan sindrom antifosfolipid (APS). ${ }^{1}$

Belum diketahui faktor risiko yang berpengaruh dengan kejadian Preeklampsia di RSUP Dr. Kariadi Semarang. Berdasarkan penjabaran di atas, penulis tertarik untuk melakukan penelitian mengenai faktor risiko yang berpengaruh terhadap kejadian Preeklampsia di RSUP Dr. KariadiSemarang.

\section{METODE}

Desain penelitian yang digunakan dalam penelitian ini adalah survei kasus kontrol (Case Control), yakni suatu penelitian survei analitik yang menyangkut bagaimana faktor risiko dipelajari dengan menggunakan pendekatan retrospective atau mundur ke belakang. Efek dari penyakit atau status kesehatan diidentifikasi saat ini, kemudian faktor risiko diidentifikasi ada atau terjadinya pada waktu yang lalu menggunakan kelompok kasus dan kelompok kontrol. ${ }^{3}$

Jenis penelitian ini adalah penelitian kuantitatif yang data penelitiannya berupa angka-angka dan analisis yang digunakan menggunakan statistik. Pengumpulan data menggunakan instrument penelitian berupa checklist. Analisis data bersifat kuantitatif/ statistik dengan tujuan untuk menguji hipotesis yang telah ditetapkan. ${ }^{4,5}$ Penelitian ini dilakukan di RSUP Dr. Kariadi Semarang pada bulan Juni - Juli tahun 2016 dengan menggunakan data Rekam Medik bulan Januari hingga Desember 2015. Penelitian dilakukan setelah ethical clearance didapatkan dan dilampirkan dalam surat izin penelitian.

Pengambilan sampel menggunakan teknik simple random sampling, yaitu mengambil sampel secara acak tanpa memperhatikan strata yang ada dalam populasi. Kelompok kasus adalah ibu hamil dengan diagnosa Preeklampsia dan kelompok kontrol adalah ibu hamil tanpa diagnosa Preeklampsia.

Analisis data melalui prosedur bertahap.

a. Analisa univariat (Analisis deskriptif) bertujuan untuk menjelaskan karakteristik setiap variabel penelitian berupa distribusi frekuensi dan persentase dari tiap variabel.

b. Analisis multivariat untuk menganalisis keeratan pengaruh antara variabel-variabel yang ada dengan melihat nilai Odds Ratio (OR). Hubungan sebab akibat antara faktor risiko dan efek diperoleh secara tidak langsung, yakni dengan menghitung risiko relatif, yang dalam studi case control dinyatakan sebagai rasio odds (odds ratio). Ratio odds 
menunjukkan berapa besar peran faktor risiko yang diteliti terhadap terjadinya penyakit (efek).

\section{HASIL DAN DISKUSI}

\section{a. Analisa univariat}

Pada variabel riwayat Preeklampsia, dari semua penderita Preeklampsia (kelompok kasus), 7 (13,2\%) responden mempunyai riwayat Preeklampsia sedangkan pada responden yang tidak mengalami Preeklampsia (kelompok kontrol) yang mempunyai riwayat Preeklampsia sebanyak $2(3,77 \%)$. Terdapat proporsi yang lebih besar pada kelompok kasus.

Jumlah responden yang mengalami kehamilan gemeli pada variabel kehamilan gemeli berjumlah 2 (3,77\%), baik pada kelompok kasus maupun kelompok kontrol. Ibu hamil yang mempunyai DM dalam

\begin{tabular}{|c|c|c|c|c|c|c|c|}
\hline \multicolumn{8}{|c|}{$\begin{array}{l}\text { Distribusi frekuensi faktor-faktor yang berpengaruh terhadap kejadian Preeklampsia } \\
\text { pada ibu hamil di RSUP Dr. Kariadi Semarang tahun } 2015\end{array}$} \\
\hline Faktor risiko & & Kasus & $\%$ & Kontrol & $\%$ & Total & $\%$ \\
\hline \multirow[t]{2}{*}{ Riwayat Preeklampsia } & Ya & 7 & 13,2 & 2 & 3,77 & 9 & 8,49 \\
\hline & Tidak & 46 & 86,98 & 51 & 96,23 & 97 & 91,5 \\
\hline \multirow[t]{3}{*}{ Kehamilan multipel } & Ya & 2 & 3,77 & 2 & 3,77 & 4 & 3,77 \\
\hline & Tidak & 51 & 96,23 & 51 & 96,23 & 102 & 96,23 \\
\hline & Total & 53 & 100 & 53 & 100 & 106 & 100 \\
\hline \multirow[t]{3}{*}{ DM } & Ya & 2 & 3,77 & 1 & 1,89 & 3 & 2,83 \\
\hline & Tidak & 51 & 96,23 & 52 & 98,11 & 103 & 97,17 \\
\hline & Total & 53 & 100 & 53 & 100 & 106 & 100 \\
\hline \multirow[t]{2}{*}{ Hipertensi kronis } & Ya & 9 & 16,98 & 0 & 0 & 9 & 8,5 \\
\hline & Tidak & 44 & 83,02 & 53 & 100 & 97 & 91,5 \\
\hline \multirow[t]{3}{*}{ Penyakit ginjal kronis } & Ya & 1 & 1,89 & 0 & 0 & 1 & 0,94 \\
\hline & Tidak & 52 & 98,11 & 53 & 100 & 105 & 99,06 \\
\hline & Total & 53 & 100 & 53 & 100 & 106 & 100 \\
\hline \multirow[t]{3}{*}{ APS } & Ya & 1 & 1,89 & 0 & 1,89 & 2 & 1,89 \\
\hline & Tidak & 52 & 98,11 & 52 & 98,11 & 104 & 98,11 \\
\hline & Total & 53 & 100 & 53 & 100 & 106 & 100 \\
\hline \multirow[t]{3}{*}{ IMT } & Obesitas (>35) & 14 & 26,41 & 4 & 7,55 & 18 & 16,98 \\
\hline & Normal (<35) & 39 & 73,58 & 49 & 92,45 & 88 & 83,02 \\
\hline & Total & 53 & 100 & 53 & 100 & 106 & 100 \\
\hline \multirow[t]{3}{*}{ Usia } & Berisiko (>40 th) & 7 & 13,2 & 5 & 9,43 & 12 & 11,32 \\
\hline & Tidak (<40 th) & 46 & 86,8 & 48 & 90,57 & 94 & 88,68 \\
\hline & Total & 53 & 100 & 53 & 100 & 106 & 100 \\
\hline \multirow[t]{3}{*}{ Paritas } & Berisiko (0) & 23 & 43,4 & 26 & 49,05 & 49 & 46,23 \\
\hline & Tidak (>1) & 30 & 56,6 & 27 & 50,95 & 57 & 53,77 \\
\hline & Total & 53 & 100 & 53 & 100 & 106 & 100 \\
\hline \multirow[t]{2}{*}{ Jarak Kehamilan } & Ya & 10 & 18,87 & 5 & 9,09 & 15 & 14,15 \\
\hline & Tidak & 43 & 81,13 & 48 & 90,91 & 91 & 85,95 \\
\hline \multirow[t]{3}{*}{ Riwayat menikah } & $>1$ kali & 0 & 0 & 4 & 7,55 & 4 & 3,77 \\
\hline & 1 kali & 53 & 100 & 49 & 92,45 & 102 & 96,23 \\
\hline & Total & 53 & 100 & 49 & 100 & 106 & 100 \\
\hline
\end{tabular}


penelitian ini pada kelompok kasus, sebanyak $2(3,77 \%)$ responden dan pada kelompok kontrol sebanyak $1(1,88 \%)$ responden. Pada variabel hipertensi kronis, dari kelompok kasus sebanyak 9 (16,98\%) responden adalah ibu hamil dengan Hipertensi kronis dan tidak ada satupun $(0 \%)$ dari kelompok kontrol adalah ibu hamil

\begin{tabular}{|c|c|c|c|c|c|}
\hline \multirow[t]{2}{*}{ Faktor risiko } & & \multicolumn{2}{|c|}{ Kelompok f } & \multirow[t]{2}{*}{ Total } & \multirow[t]{2}{*}{ Odds Ratio } \\
\hline & & Kasus & Kontrol & & \\
\hline \multirow[t]{3}{*}{ Riwayat Pre Eklamsi } & $\mathrm{Ya}$ & 7 & 2 & 9 & 3,880 \\
\hline & Tidak & 46 & 51 & 97 & \\
\hline & Total & 53 & 53 & 106 & \\
\hline \multirow[t]{3}{*}{ Kehamilan multipel } & Ya & 2 & 2 & 4 & 1,000 \\
\hline & Tidak & 51 & 51 & 102 & \\
\hline & Total & 53 & 53 & 106 & \\
\hline \multirow[t]{3}{*}{ DM } & $\mathrm{Ya}$ & 2 & 1 & 3 & 2,039 \\
\hline & Tidak & 51 & 50 & 103 & \\
\hline & Total & 53 & 53 & 106 & \\
\hline \multirow[t]{3}{*}{ Hipertensi kronis } & Ya & 9 & 0 & 9 & 12 \\
\hline & Tidak & 44 & 53 & 97 & \\
\hline & Total & 53 & 53 & 106 & \\
\hline \multirow[t]{3}{*}{ Penyakit Ginjal Kronis } & Ya & 2 & 1 & 1 & 2,038 \\
\hline & Tidak & 53 & 54 & 107 & \\
\hline & Total & 55 & 55 & 110 & \\
\hline \multirow[t]{3}{*}{ APS } & Ya & 1 & 1 & 2 & 1,000 \\
\hline & Tidak & 52 & 52 & 104 & \\
\hline & Total & 53 & 53 & 106 & \\
\hline \multirow[t]{3}{*}{ IMT } & $\geq 35$ & 14 & 4 & 18 & 4,397 \\
\hline & $<35$ & 39 & 49 & 88 & \\
\hline & Total & 53 & 53 & 106 & \\
\hline \multirow[t]{3}{*}{ Usia } & $\geq 40$ & 7 & 5 & 12 & 1,461 \\
\hline & $<40$ & 46 & 48 & 94 & \\
\hline & Total & 53 & 53 & 106 & \\
\hline \multirow[t]{3}{*}{ Riwayat Paritas } & Nulipara & 23 & 26 & 49 & 0,796 \\
\hline & Multipara & 30 & 27 & 57 & \\
\hline & Total & 53 & 53 & 106 & \\
\hline \multirow[t]{3}{*}{ Jarak kehamilan } & Berisiko ( $\geq 10$ th) & 10 & 5 & 15 & 2,233 \\
\hline & Tidak (<10 th) & 43 & 48 & 91 & \\
\hline & Total & 53 & 53 & 106 & \\
\hline \multirow[t]{3}{*}{ Riwayat menikah } & $>1$ kali & 1 & 5 & 6 & 0,185 \\
\hline & 1 kali & 52 & 48 & 100 & \\
\hline & Total & 53 & 53 & 106 & \\
\hline
\end{tabular}


dengan Hipertensi kronis. Proporsi kehamilan dengan hipertensi kronis lebih banyak terdapat pada kelompok kasus. Jumlah responden kehamilan dengan penyakit ginjal hanya ada $1(1,89 \%)$ di kelompok kasus, tidak ada $(0 \%)$ responden pada kelompok kontrol. Pada variabel penyakit APS baik pada kelompok kasus maupun kelompok kontrol, keduanya mempunyai responden kehamilan dengan penyakit APS sebanyak 1 (1,88\%). Pada penelitian ini jumlah responden dengan IMT $\geq 35$ pada kelompok kasus sebanyak 14 (26,41\%) dan sebanyak 4 (7,55\%) pada kelompok kontrol. Responden dengan IMT $\geq 35$ lebih banyak terdapat pada kelompok kasus,

Variabel berikutnya adalah usia. Pada kelompok kasus jumlah responden yang berusia $\geq 40$ tahun adalah sebanyak $7(13,2 \%)$ sedangkan pada kelompok kontrol sebanyak $5(9,43 \%)$. Proporsinya hampir seimbang antara kelompok kasus dan kelompok kontrol.Jumlah responden nulipara atau ibu hamil yang belum pernah melahirkan bayi viable (hidup) termasuk diantaranya primipara pada kelompok kasus berjumlah sebanyak 23 (43,4\%). Pada kelompok kontrol terdapat jumlah yang hampir sama yaitu sebanyak 26 (49,05\%) responden.

Pada variabel jarak kehamilan $\geq 10$ tahun, pada kelompok kasus adalah sebanyak 10 (18,87\%) responden sedangkan pada kelompok kontrol adalah sebanyak $5(9,09 \%)$ responden. Proporsinya dua kali lipat pada kelompok kasus daripada pada kelompok kontrol. Tidak ada $(0 \%)$ responden yang mempunyai riwayat menikah $>1$ kali pada kelompok kasus dan justru terdapat $4(7,55 \%)$ responden yang mempunyai riwayat menikah $>1$ kali pada kelompok kontrol.

\section{b. Analisis multivariat}

Tabel 2 menunjukkan faktor risiko yang berpengaruh terhadap kejadian Preeklampsia pada ibu hamil di RSUP Dr. KariadiSemarang.

\section{Kejadian Preeklampsia}

Selama tahun 2015 di RSUP Dr. Kariadi Semarang terdapat 327 kejadian Preeklampsia (20,63\%) dari 1585 ibu hamil yang dirawat. Dalam penelitian ini frekuensi kejadian Preeklampsia mencapai 20\% dari seluruh kehamilan di RSUP Dr. Kariadi Semarang. Hal ini terjadi karena ibu hamil yang datang ke sebagian besar mengalami komplikasi atau mempunyai kondisi patologis. Jadi dapat dipahami mengapa frekuensi kejadian Preeklampsia dalam penelitian ini mencapai $20 \%$.

\section{Faktor risiko yang berpengaruh terhadap kejadian Preeklampsia pada kehamilan}

\section{a. Riwayat Preeklampsia}

Hasil analisis bivariat menunjukkan ibu hamil dengan riwayat Preeklampsia berisiko 3,898 kali mengalami Preeklampsia dibanding ibu hamil tanpa riwayat Preeklampsia. Riwayat Preeklampsia pada kehamilan sebelumnya adalah faktor risiko utama. ${ }^{1}$ Menurut Duckit risiko meningkat hingga 7 kali lipat. Hasil ini serupa dengan penelitian Shamsi di Pakistan. ${ }^{1,6}$ Menurut Hurt kehamilan dengan Preeklampsia yang muncul pada trimester II, 65\% akan kambuh sehingga suplementasi minyak ikan, vitamin C, vitamin E, ataupun anti hipertensi tidaklah efektif. ${ }^{7} \mathrm{Hal}$ ini sesuai dengan teori serta penelitian sebelumnya bahwa riwayat Preeklampsia pada kehamilan sebelumnya merupakan faktor risiko kejadian Preeklampsia, sehingga memperkuat teori/konsep-konsep terjadinya Preeklampsia pada ibu hamil.

\section{b. Kehamilan multipel}

Kehamilan tunggal atau multipel memiliki risiko yang sama untuk terjadi Preeklampsia sehingga kehamilan multipel bukanlah faktor risiko Preeklampsia. Hasil ini bertentangan dengan teori hiperplasentosis bahwa kehamilan multipel berisiko berkembang menjadi Preeklampsia. Kejadian Preeklampsia pada kehamilan multipel meningkat menjadi 4-5 kali dibanding pada kehamilan tunggal. Dilaporkan bahwa kejadian Preeklampsia akan meningkat pada kehamilan ketiga dan seterusnya.

Beberapa respon fisiologis ibu yang normal terhadap kehamilan diperburuk oleh adanya janin ganda. Beratnya rahim dapat menyebabkan kompresi lebih jauh pada pembuluh yang besar, yang mengakibatkan pengurangan aliran darah rahim lebih banyak akibat kompresi aorta, hipotensi supinasi, ataupun keduanya. Pada keadaan seperti ini, edema dan proteinuria sering ditemukan.

Teori iskemik placenta turut mendukung hipotesis bahwa kehamilan multipel berhubungan dengan kejadian Preeklampsia. Preeklampsia banyak ditemukan pada primi dengan bayi besar atau kehamilan gemeli atau polihidramnion atau hamil mola. Peningkatan regangan pada dinding rahim akan meningkatkan resistensi pembuluh darah sehingga mengakibatkan hipertensi yang menjadi Preeklampsia. ${ }^{1,8,9}$ Hasil berbeda bisa terjadi karena variasi responden yang terbatas dan waktu penelitian yang singkat. Sampel yang didapatkan hanya kehamilan gemeli, tapi tidak didapatkan kehamilan triplet dan seterusnya. Tapi hasil ini serupa dengan Hanum dan Afridasari bahwa kehamilan kembar dan plasentosis tidak berhubungan dengan kejadian Preeklampsia karena terjadinya Preeklampsia tidak hanya dipengaruhi oleh satu faktor saja. ${ }^{10,11}$

\section{c. Penyakit Diabetes Mellitus (DM)}

Responden dengan kehamilan DM tidak banyak tetapi secara statistik berisiko 2,041 kali terjadi Preeklampsia 
dibanding ibu hamil tanpa DM. Shamsi di Iran mengemukakan hasil serupa bahwa DM pada kehamilan meningkatkan risiko kejadian Preeklampsia. Ada hubungan erat antara resistensi insulin, DM tipe II, dan hipertensi. ${ }^{12}$ Hiperinsulinemia akan menstimulasi sel-sel otot polos pembuluh darah, meningkatakan aktivitas sistem saraf simpatik dan modifikasi transport transmembran seperti retensi sodium dan berhubungan dengan disfungsi endotel. Salah satu teori terjadinya Preeklampsiaadalah karena adanya disfungsi endotel. ${ }^{9}$ Hal ini sesuai dengan teori yang ada.

\section{d. Penyakit Hipertensi kronis}

Hipertensi kronis adalah salah satu hal penting dan mudah sebagai penanda faktor risiko Preeklampsia dibanding penanda biokimia lainnya. Selama 100 tahun terakhir banyak uji klinis, biofisik dan biokimia disarankan untuk mengidentifikasi wanita yang berisiko terhadap kejadian Preeklampsia hanya saja sensitivitasnya terbatas dan mahal untuk memprediksi kejadian Preeklampsia. Riwayat hipertensi kronis dapat ditanyakan sebagai alat skrining yang mudah dan terjangkau untuk memonitor kejadian Preeklampsia pada ibu hamil selama awal kehamilan.

Penelitian Shamsi dan Karima menunjukkan hasil yang sama sekalipun dalam seting wilayah dan populasi yang berbeda, bahwa hipertensi kronis berhubungan dengan kejadian Preeklampsia pada kehamilan. ${ }^{12,13} \mathrm{Hal}$ ini dimungkinkan karena adanya resistensi insulin yang akan mengaktifkan sistem saraf simpatik yang juga mengaktifkan reabsorpsi tubular sodium yang akan memperberat tingkat oksidative sitokinin, yang akan mengakibatkan Preeklampsia. ${ }^{14-16}$

\section{e. Penyakit ginjal}

Penyakit penyerta dalam kehamilan termasuk penyakit ginjal adalah faktor risiko utama terjadinya Preeklampsia pada kehamilan. ${ }^{1}$ Penelitian ini menunjukkan hasil bahwa ibu hamil dengan penyakit ginjal berisiko 2,038 kali menderita Preeklampsia daripada ibu hamil yang tidak mempunyai penyakit ginjal. Komplikasi pada kehamilan dan persalinan dipengaruhi oleh status kesehatan di masa kehamilan atau sebelum masa kehamilan. Hasil serupa dikemukakan oleh Shamsi. ${ }^{6}$ Walaupun tidak secara jelas menyebut penyakit ginjal, tapi penelitian Yulianti juga menyebutkan bahwa ada hubungan bermakna antara penyakit penyerta kehamilan dengan kejadian Preeklampsia dan berisiko 22 kali lebih besar mengalami kejadian Preeklampsia dalam kehamilannya. ${ }^{17}$ Hurt mengatakan bahwa langkah preventif yang paling efektif untuk Preeklampsia adalah evaluasi kesehatan dini, mengurangi faktor risiko, dan mengoptimalkan kesehatan maternal. ${ }^{7}$ Ini berarti bahwa penyakit ginjal berisiko terhadap kejadian Preeklampsia. Seyogyanya ibu hamil tidak mempunyai penyakit penyerta kehamilan agar kehamilannya tetap sehat dan tidak terjadi komplikasi, baik untuk ibu maupun janinnya.

\section{f. Penyakit APS}

Hasil analisis data menunjukkan bahwa ibu hamil dengan penyakit APS atau tanpa penyakit APS mempunyai risiko yang sama untuk mengalami Preeklampsia pada kehamilannya. Penyakit APS bukanlah faktor risiko Preeklampsia. Hasil ini berbeda dengan literatur dan penelitian Yulianti serta Shamsi. ${ }^{6,17}$ Ducckit mengatakan bahwa adanya antibody antifosfolipid (antibody antikardiolipin, antikoagulan lupus atau keduanya) meningkatkan risiko Preeklampsia pada kehamilan hampir 10 kali lipat. ${ }^{1}$ Hasil berbeda mungkin saja terjadi karena keterbatasan jumlah responden dan waktu penelitian sehingga tidak semua ibu hamil dengan APS dapat dianalisis datanya. Perlu penelitian dengan jumlah sampel yang lebih banyak dan dengan waktu yang lebih lama.

\section{g. IMT}

Ibu hamil dengan IMT $\geq 35$ atau obesitas berhubungan erat dengan kejadian Preeklampsia dan berisiko 4 kali mengalami Preeklampsia dibanding ibu hamil yang tidak obesitas. Hasil penelitian ini serupa dengan penelitian Karyati.Hubungan obesitas dan Preeklampsia mungkin disebabkan hiperlipidemia dengan densitas lipoprotein yang mempengaruhi tekanan oksidative dan kerusakan sel endotel. ${ }^{18,19}$ Hasil berbeda dikemukakan oleh Shamsi bahwa obesitas tidak berhubungan dengan kejadian Preeklampsia. ${ }^{12} \mathrm{Hal}$ ini mungkin terjadi karena batasan mengenai berapa IMT yang dikatakan obesitas tidaklah sama. Penulis mengambil acuan obesitas berdasar PNPK Preeklampsia yaitu IMT $\geq 35$.,14,15

\section{h. Usia}

Usia merupakan faktor risiko Preeklampsia. Ibu hamil dengan usia $\geq 40$ tahun berisiko 1,4 kali terjadi Preeklampsia dibanding ibu hamil yang berusia $<40$ tahun. Hal ini sedikit berbeda dengan penelitian Indriani bahwa memang usia tua ( $>35$ tahun) ada hubungan erat dengan kejadian Preeklampsia dan berisiko 3 kali lebih besar mengalami Preeklampsia, serupa dengan penelitian Karima dan Hanumbahwa usia berisiko ( $<20$ tahun dan $>35$ tahun) berhubungan dengan kejadian Preeklampsia. ${ }^{10,13,20}$

Secara teori usia memang berpengaruh pada kejadian Preeklampsia. Tetapi Karyati menyatakan bahwa tidak ada hubungan antara usia dengan kejadian Preeklampsia. ${ }^{18}$ Hasil yang berbeda dikarenakan parameter usia berisiko yang digunakan berbeda dengan penelitian-penelitian sebelumnya. Penulis mengacu pada PNPK Preeklampsia dan ACOG (American College of Obstetrcian and Gynecologist) dimana usia berisiko adalah $\geq 40$ tahun. ${ }^{1,14,15}$ 


\section{i. Paritas}

Preeklampsia-eklamsia hampir secara ekslusif merupakan penyakit pada nullipara. ${ }^{20}$ Proporsi nulipara maupun multipara hampir berimbang pada kelompok kasus maupun kelompok kontrol. Hasil analisis data memperlihatkan bahwa nulipara berisiko 0,8 kali terjadi Preeklampsia dibanding pada multipara, yang berarti bahwa nulipara adalah faktor protektif Preeklampsia. Hasil senada dikemukakan oleh Karyatibahwa paritas tidak berhubungan dengan kejadian Preeklampsia. ${ }^{18}$ Hasil ini dapat disebabkan pada ibu multipara bisa saja mempunyai faktor risiko Preeklampsiayang lain sehingga dalam penelitian ini ibu nulipara mempunyai risiko tidak sebesar yang dikemukakan dalam teori yaitu sebesar 4-7 kali.

\section{j. Jarak kehamilan}

Wanita multipara dengan jarak kehamilan sebelumnya 10 tahun atau lebih memiliki risiko Preeklampsia hampir sama dengan nulipara. Risiko Preeklampsia meningkat sesuai dengan interval dengan kehamilan pertama (1,5 setiap 5 tahun jarak kehamilan pertama dan kedua; $\mathrm{p}<0,0001$ ) (Robillard dkk ). ${ }^{1}$ Penelitian ini menunjukkan bahwa jarak kehamilan $\geq 10$ tahun berisiko 2,23 kali mengalami Preeklampsia dibanding wanita dengan jarak kehamilan <10 tahun. Hasil serupa dengan yang dilakukan oleh Shamsi. Jarak kehamilan yang lama (>10 tahun) dikaitkan dengan reaksi tubuh akan adanya proses kehamilan. Proses pembentukan placenta akan menyebabkan kerusakan endotel yang merupakan salah satu teori terjadinya Preeklampsia. 6,9,16

\section{k. Riwayat menikah}

Kehamilan pertama oleh pasangan yang baru dianggap sebagi faktor risiko karena faktor risiko meningkat pada wanita yang memiliki paparan rendah terhadap sperma. ${ }^{5}$ Hal ini dikaitkan dengan kemungkinan adanya riwayat Preeklampsia yang diturunkan dari pasangan saat ini. Preeklampsia adalah penyakit genetik yang diturunkan. Pada penelitian ini riwayat menikah $>1$ kali berisiko 0,185 kali terjadi Preeklampsia, yang berarti bahwa menikah >1 kali merupakan faktor protektif Preeklampsia. Pasangan baru tidak berarti adalah pernikahan kedua dan seterusnya tapi adalah kehamilan dengan pasangan berbeda terlepas dari status pernikahan.

Penelitian ini menggunakan rekam medis sesuai yang tertulis yaitu status pernikahan tanpa bisa menanyakan lebih lanjut mengenai kehamilan oleh pasangan baru. Jadi dalam penelitian kali ini riwayat menikah tidak bisa disamakan dengan kehamilan oleh pasangan baru. Belum ada penelitian yang meneliti variabel mengenai riwayat menikah atau kehamilan oleh pasangan baru sesuai dengan literatur yang penulis punyai.

\section{SIMPULAN}

Dari hasil penelitian ini dapat disimpulkan bahwa dari 11 variabel yang diteliti 7 variabel adalah faktor risiko, 2 variabel adalah faktor protektif, dan 2 variabel adalah bukan faktor risiko Preeklampsia. Faktor risiko tersebut adalah: riwayat Preeklampsia (OR 3,88), penyakit DM (OR 2,039), penyakit ginjal (OR 2,038), Hipertensi kronis (OR 12), IMT (OR 4,397), usia (OR 1,461), dan jarak kehamilan (OR 2,233). Faktor risiko yang paling berpengaruh adalah Hipertensi kronis. Paritas (OR 0,796) dan riwayat menikah (OR 0,185) adalah variabel yang merupakan faktor protektif Preeklampsia. Kehamilan multipel dan penyakit APS dalam penelitian ini bukanlah faktor risiko kejadian Preeklampsia.

Masyarakat diharapkan menghindari faktor risiko Preeklampsia atau mengelolanya sejak dini agar tidak terjadi kejadian Preeklampsia pada kehamilan. Masyarakat diharapkan tidak hamil atau hamil dengan pengawasan ketat bila mempunyai Hipertensi kronis karena berisiko 12 kali mengalami kejadian Preeklampsia. Masyarakat diharapkan selalu memeriksakan kehamilan sejak dini ke petugas kesehatan agar dapat dilakukan deteksi dini mengenai faktor risiko Preeklampsia untuk kemudian dapat dikelola dengan baik.

RSUP Dr. Kariadi hendaknya memberikan rujuk balik agar pasien-pasien tersebut dapat dikelola dengan baik di tempat semula setelah pulang dari perawatan di RSUP Dr. KariadiSemarang.

Poltekkes hendaknya memberikan materi perkuliahan mengenai Preeklampsia secara update sehingga nantinya akan sangat bermanfaat bagi mahasiswa ketika memberikan pelayanan di masyarakat. Dan menambah literatur mengenai faktor risiko Preeklampsia pada kehamilan.

Peneliti selanjutnya hendaknya juga meneliti ada tidaknya hubungan antara faktor risiko dengan kejadian Preeklampsia dan melakukan penelitian faktor risiko Preeklampsia dengan variabel terikat yang berbeda. Hendaknya penelitian berikutnya membedakan antara kejadian Preeklampsia, Impending Eklampsia, Eklampsia, ataupun HELLP syndrome.

\section{DAFTAR PUSTAKA}

1. Kementrian Kesehatan Republik Indonesia. Pedoman Nasional Pelayanan Kedokteran : Diagnosis dan Tatalaksana Pre Eklamsia. Jakarta : Kementrian Kesehatan Republik Indonesia, 2015

2. Dinas Kesehatan Kota Semarang. Profil Kesehatan Kota Semarang 2014. Semarang: Pemerintah Kota Semarang, 2015.

3. Notoatmojo S. Metodologi Penelitian Kesehatan Ed. Rev. Jakarta : Rineka Cipta, 2012.

4. Sugiono. Metode Penelitian Pendidikan (Pendekatan Kuantitatif, Kualitatif, dan RED). Bandung: Alfabeta, 2011.

5. Sastroasmoro S, Ismael S. Dasar-dasar Metodologi Penelitian Klinis Edisi ke-4. Jakarta: CV Sagung Seto, 2011.

6. Shamsi et al. Epidemiology and risk factors of preeclampsia; an 
overview of observational studies. Pakistan : Al Ameen J Med Sc i 2013; 6(4):292-300.

7. Hurt JK, Guile MW, Blenstock J, et al. The John Hopkins Manual of Gynecology and Obstetrics Fourth edition. Baltimore, Maryland : Lippincott Williams and Wilkins (LWW), 2011.

8. Moore, Hacker. Essensial Obstetri dan Ginekologi edisi 2. Jakarta : Penerbit Buku Kedokteran EGC, 2001.

9. Cunningham, dkk. Williams Obstetri edisi 23 volume 1. Jakarta: penerbit Buku Kedokteran EGC, 2010.

10. Huda FH. Faktor Risiko yang Berhubungan dengan Kejadian Preeklampsia Pada Ibu Bersalin di RSUP Dr. M. Djamil Padang. Jurnal of Public Health vol3 no.22013

11. Afridasari SN, Saimiin J, Sulastrianah S. Analisis Faktor Risiko Kejadian Preeklamsia. Medula vol.1, no.12013

12. Shamsi et al. Aemulticentre matched case control study of risk factors for Preeclampsia in healthy women in Pakistan. BMC Women's Health 2010. http://www.biomedcentral.com/1472-6874/ 10/14 (Diakses 01 November 2015).

13. Karima NM, dkk. Hubungan Faktor Risiko dengan Kejadian Pre-eklampsia Berat di RSUP Dr. M. Djamil Padang. Jurnal Kesehatan Andalas 2015; 4(2). http://jurnal.fk.unand.ac.id (diakses 17 November 2015).

14. The American College of Obstetricians and Gynecologists. New Guidelines in Preeclampsia Diagnosis and Care Include Revised Definition of Preeclampsia. Washington: The American College of Obstetricians and Gynecologists, 2013
15. The American College of Obstetricians and Gynecologists. Hypertension in Pregnancy. Washington : The American College of Obstetricians anf Gynecologists, 2013 http://www.acog.org/-/media/District(diakses 4 Februari 2016).

16. Uzan, J et al. Pre-eclampsia: pathophysiology, diagnosis, and management. Vascular health and Risk Management, 2011. http:/ / dx.doi.org/10.2147/VHRM.S20 (diakses 17 November 2015)

17. Yulianti L, Fikawati S. Pre-Eklampsia Berat di RSUD Bayu Asih Purwakarta. Jurnal Kesehatan Masyarakat Nasional vol 3 no.12008

18. Karyati S. Faktor-faktor yang Berkontribusi pada Kejadian Preeklampsia di RSU PKU Muhammadiyah Gubug Tahun 2014. JIKK Vol. 5. No. 3 Agustus 2014: 48-60.

19. JeyabalanA. Epidemiology of preeclampsia : impact of obesity. Nurition Reviews. 2013 http://www.almetric.com/ details.php?domain=onlinelibrary.wilwy.com\&citation_id=1 873130(diakses 01 November 2015).

20. Winknjosastro, H, Saifuddin, A. B. (Ed.). Trijatmo. Ilmu Kebidanan. Jakarta : Yayasan Bina Pustaka Sarwono Prawirohardjo, 2006. 